\title{
Developing and Validating the Educational Materials for a Nurse-Led Self-Management Education in Adults with Type 2 Diabetes
}

\author{
Golnaz Azami ${ }^{a}$ b Kim Lam Soh ${ }^{a}$ Shariff-Ghazali Sazlina ${ }^{c}$ Md.Said Salmiah $^{d}$ \\ Sanaz Aazami ${ }^{\mathrm{b}}$ Moseyed Mozafarib Hamid Taghinejad ${ }^{\mathrm{b}}$ Behzad Badakhsh $^{\mathrm{e}}$ \\ ${ }^{a}$ Department of Nursing and Rehabilitation, Faculty of Medicine and Health Sciences, University Putra Malaysia \\ (UPM), Serdang, Malaysia; ${ }^{b}$ Department of Nursing, Faculty of Nursing and Midwifery, Ilam University of Medical \\ Sciences, Ilam, Iran; ${ }^{C}$ Department of Family Medicine, Faculty of Medicine and Health Sciences, University Putra \\ Malaysia (UPM), Serdang, Malaysia; d Department of Community Health, Faculty of Medicine and Health Sciences, \\ University Putra Malaysia (UPM), Serdang, Malaysia; ${ }^{e}$ Department of Internal Medicine, Faculty of Medicine, Ilam \\ University of Medical Sciences, Ilam, Iran
}

\section{Keywords}

Self-efficacy · Intervention · Self-management · Diabetes · Type 2 diabetes V Validation

\begin{abstract}
Background: Diabetes education and self-care are the cornerstones of diabetes management. There are few nurse-led structured diabetes management programs available in Iran. Objectives: This paper aims to develop and validate a nurse-led diabetes self-management intervention for patients with type 2 diabetes. Method: The theoretical framework underpinning the intervention was the Bandura's selfefficacy theory. The seven basic steps of the Taba model were used to develop and validate the study intervention. Results: The preliminary results from this study suggest that the study intervention was carefully contextualized and linked to the existing diabetes care. Overall, the intervention was very well received and appreciated by the respondents. Conclusion: This was the first known validated nurse-led diabetes self-management intervention available in the Persian Language.

(c) 2019 The Author(s)

Published by S. Karger AG, Basel
\end{abstract}

\section{Introduction}

Type 2 diabetes mellitus (T2DM) is one of the most common endocrine disorders, which affects almost $6 \%$ of the adult population worldwide [1-3]. According to recent estimates, the total number of patients living with diabetes is expected to rise significantly from 176 million in 2000 to 370 million in 2030, with more than four-fifths of them living in developing countries [4].

Iran, also known as Persia, is a developing country located in West Asia. It has been reported that there were more than 4.6 million Iranian adults with diabetes in 2015 , a number which is expected to exceed 9.2 million by 2040 [5]. In Iran, T2DM accounts for $90 \%$ of all diabetes cases and occurs predominantly in middle-aged and older population, with an average age of 40-50 years. T2DM typically affects Iranian patients in the most productive years of their lives. This becomes even more challenging when taking into account that the average age of diabetes patients in developed countries is significantly higher (over 65 years of age) [6]. With the prolongation of the average life expectancy, the occurrence of T2DM in the younger age groups will lead to the escalation of the

Golnaz Azami

Department of Nursing and Rehabilitation, University Putra Malaysia Selangor Darul Ehsan

Serdang, Selangor 43400 (Malaysia)

E-Mail golnaz.azami64@gail.com 
disease-related disability-adjusted life years in Iran [7]. Thus, the prevention of serious complications, subsequent development of clinical disabilities, and patient's quality of life completely depend on early diagnosis and adequate management of diabetes [7].

Nowadays, self-management education is considered to be an integral component of diabetes care. Diabetes self-management education (DSME) has been defined as "the ongoing process of facilitating the knowledge, skill, and ability necessary for diabetes self-care" [8]. Different types of healthcare professionals can deliver DSME. Evidence related to the effectiveness of different disciplines for education have not established clear differences in the quality of services delivered by different types of healthcare professionals [9]. However, current evidence favors the registered nurses, nutritionist, and pharmacist [9]. Among healthcare professionals, nurses are the largest and most trusted group of healthcare workforce serving as the primary instructor for the DSME and as a member of the multidisciplinary team assisting the designing and delivering the diabetes education [9].

The national committee for diabetes, a subdivision of Iran's ministry of health $(\mathrm{MOH})$, issued the development of optimal policies and programs for prevention and control of diabetes in Iran. Despite the availability of national guidelines for diabetes management, there is still limited nurse-led DSME available for patients with T2DM in Iran [10]. Even though patients with diabetes expressed a need for greater access to culturally appropriate education, there are limited comprehensive self-management education programs [10-13]. There is a strong need for well-designed, high-quality nurse-led diabetes self-management interventions that could lead to substantial improvements in clinical outcomes of patients with T2DM. The main purpose of this paper was to review the existing usual diabetes education programs in Iran and consequently develop and validate a nurse-led DSME suitable and tailored for Iranian setting.

\section{Methods}

We used the Taba model to develop the study intervention [14]. The seven basic steps involved in the intervention development process are presented in Figure 1.

\section{Need Assessment}

Before we started our project, we conducted a need analysis to learn about important issues and problems faced by patients with T2DM in order to design an effective educational program. For this purpose, we reviewed the existing diabetes education program in Iran. Then, we compared it to standard education programs

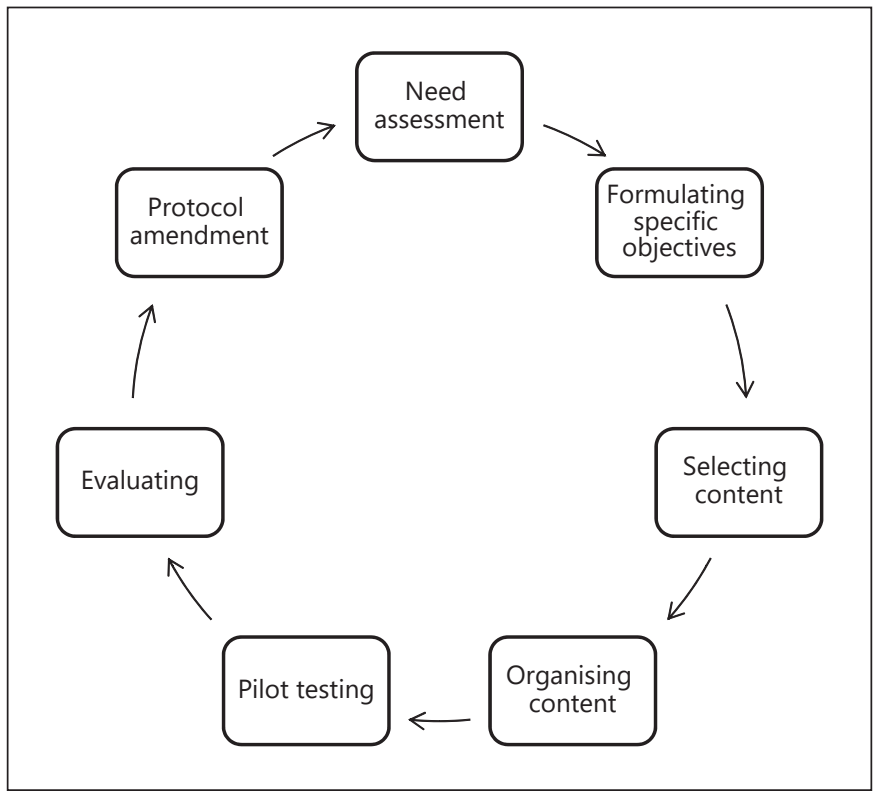

Fig. 1. The seven basic steps involved in the intervention development process adapted from the Hilda Taba model [14].

commonly utilized in other countries. Our first step in data collection was to collect existing material in use for diabetes education. The researcher obtained diabetes education material. The usual diabetes care is based on the recommendation of the practice guidelines $(\mathrm{MOH})$ for the management of diabetes. The usual care involves medications, lifestyle modification (diet, physical activity, monitoring, feet care) and education on self-management. Clinical examination and laboratory tests are generally conducted at each visit in accordance with the national diabetes guidelines. Based on the result of the laboratory tests and examination, individual counseling, recommendation, and renewal of prescribed medication are given at these checkups. The usual care involves a multidisciplinary team approach and comprises care by the physicians, diabetes nurse educator, nutritionist, pharmacist and, if necessary, shared care with the ophthalmologist and endocrinologist. The main characteristic of usual diabetes care is presented in Table 1. The usual care is provided on an individual basis at regular intervals, varying from thrice to four times a year, with the duration of 20-30 min per appointment and is offered in the form of face-toface lecturing, pamphlets, and broadsheets. The content and learning materials consist of a small amount of information. It appears to be mostly confined to the five pillars of diabetes management, i.e. diet, physical activity, medication, blood glucose monitoring, and foot care.

Comparison of Existing Local Diabetes Care to Standard

Education Programs

In the next step, we compared the existing local diabetes care with standard education programs commonly utilized in other countries. The American Association of Diabetes Educators (AADE) defined seven essential self-care behaviors for successful and effective diabetes self-management [15]. These seven self-care behaviors include healthy eating, being active, monitoring, taking 
medication, problem-solving, reducing risk, and healthy coping [15]. The majority of these essential self-care behaviors are not embedded in the existing usual care. It is obvious that there is a big gap in the usual care education. Thus, the present study was designed with the aim of filling this information gap.

\section{Formulating Specific Objectives}

The specific objectives were:

- Develop a nurse-led DSME for Iranian adults with T2DM, based on self-efficacy theory.

- Validate the developed intervention for Iranian adults with T2DM.

\section{Selecting the Content}

Step 1: Theoretical Background

Intervention studies with a clear theoretical basis and a strong design are more effective than those without an explicit theoretical foundation [16-18]. A growing body of evidence does indeed suggest that programs incorporating behavioral and psychosocial strategies with or without cross-cultural adaptation lead to improvement in patient outcomes $[8,19]$. Self-efficacy is the most commonly adopted theoretical framework for promoting selfmanagement behaviors, whereby patients with higher self-efficacy are thought better able to self-manage [20]. Thus, self-efficacy was considered an appropriate theory to underpin the development of our educational materials.

\section{Step 2: Comprehensive Review}

The study intervention involves a 12-week DSME designed to improve $\mathrm{HbAlc}$ with a follow-up at 12 and 24 weeks. The American Association of diabetes educators (AADE) defined 7 self-care behaviors essential for effective and successful diabetes self-management [15]. These 7 self-care behaviors are the core intervention components. The findings of previous systematic reviews and need assessment were used to guide the development of the study intervention. These are:

- Written materials (booklet) must be available to patients to support the education, reflect the fact that DSME involves a complex regimen, and often require changes in lifestyle. Audiovisual media such as video is a great alternative available to researchers and can ensure adequacy, accuracy, and completeness of the education content [21].

- The video presentation is potentially a more powerful tool for delivering messages and information with the aim of improving health outcomes [22].

- In general, group-based education has been found to be more effective at reducing A1c levels than individual-based education $[16,23]$.

- Telephone education has been demonstrated to be a feasible and effective method of delivering education, information, and support [24-27].

- Overall, using a combination of different methods to deliver information/education has been reported to have more promising results $[28,29]$.

Step 3: Generation of the Intervention and Judging Panel Validation

The provider experts including an endocrinologist, nutritionist, nurse, and pharmacist were invited to participate in this study. They have played an important role in helping to develop and val-
Table 1. Usual diabetes care characteristics in Iran

\begin{tabular}{|c|c|}
\hline Domains & Characteristics \\
\hline Timing & Monitoring at 3-month interval \\
\hline Mode of delivery & Face-to-face individual based \\
\hline Theoretical based & - \\
\hline Materials & $\begin{array}{l}\text { Pamphlet } \\
\text { Lecturing }\end{array}$ \\
\hline Duration & 20-30 min per appointment \\
\hline Care approach & $\begin{array}{l}\text { Multidisciplinary team approach including: } \\
\text {-Internists } \\
\text {-Diabetes nurse educator } \\
\text {-Nutritionist } \\
\text {-Pharmacist }\end{array}$ \\
\hline $\begin{array}{l}\text { Usual diabetes } \\
\text { care topics }\end{array}$ & $\begin{array}{l}\text { Diet (food group pyramid) } \\
\text { Physical activity (benefit of being active and } \\
\text { healthy, exercise rules) } \\
\text { Foot care (foot care benefits, diabetic foot } \\
\text { ulcer preventions) } \\
\text { Hypo- and hyperglycemia } \\
\text { How to use glucose meter? } \\
\text { How to inject insulin? } \\
\text { Diabetes and your eyes and kidneys }\end{array}$ \\
\hline Measures & $\begin{array}{l}\text { Laboratory test } \\
\text {-FBS or RBS (per visit) } \\
\text {-HbA1c (every } 6 \text { months) } \\
\text {-Lipid profile (every } 6 \text { months) } \\
\text {-Creatinine (annually) } \\
\text {-Liver enzyme tests (annually) } \\
\text {-Liver function tests (annually) } \\
\text {-Thyroid test (if necessary) } \\
\text {-Urine test (if necessary) } \\
\text { Clinical measurement } \\
\text {-Blood pressure (per visit) } \\
\text {-Weight (per visit) } \\
\text {-Height (per visit) } \\
\text {-BMI (per visit) } \\
\text {-Eye examination (annually) } \\
\text {-Neuropathy examination (annually) } \\
\text {-Dental care (every } 6 \text { months) } \\
\text {-Psychological evaluation (annually) } \\
\text {-Heart examination (annually) }\end{array}$ \\
\hline
\end{tabular}

idate the study intervention. The expert's views regarding the content of the intervention were obtained by the Delphi techniques with three rounds. The first round was a brainstorming question, "could you please highlight the important aspects of the management of patients with T2DM?" The second round included an evaluation of the generated intervention based on the results from the first round of discussion and information from two publicly available websites. The evaluation focused on the pertinence, coherence, adequacy, clarity, and quality of the developed intervention. The intervention was amended based on the results and comments 
Table 2. Overview of intervention plan

\begin{tabular}{|c|c|c|c|c|c|}
\hline Time & Intervention & $\begin{array}{l}\text { Self-efficacy theory } \\
\text { application }\end{array}$ & Content & Objective & $\begin{array}{l}\text { ADA } 7 \text { self-care } \\
\text { behavior application }\end{array}$ \\
\hline \multirow[t]{3}{*}{ Week 1} & $\begin{array}{l}\text { First group practice } \\
\text { session }\end{array}$ & $\begin{array}{l}\text { Performance } \\
\text { accomplishment } \\
\text { Vicarious experience } \\
\text { Verbal persuasion } \\
\text { Self-evaluation }\end{array}$ & $\begin{array}{l}\text { To introduce group members } \\
\text { To understand what diabetes is and } \\
\text { the importance of managing it } \\
\text { (watch movie and discussion) } \\
\text { To introduce self-management } \\
\text { techniques (brainstorm) } \\
\text { To introduce goal settings and } \\
\text { action plan (role modelling and } \\
\text { discussion) }\end{array}$ & \multirow[t]{3}{*}{$\begin{array}{l}\text { To be able to understand what } \\
\text { diabetes is and the importance } \\
\text { of managing it } \\
\text { To be able to understand goal } \\
\text { setting and action plan }\end{array}$} & \multirow[t]{3}{*}{$\begin{array}{l}\text { Introduction to self- } \\
\text { management } \\
\text { techniques } \\
\text { Self-directed goal } \\
\text { setting and action } \\
\text { plan }\end{array}$} \\
\hline & $\begin{array}{l}\text { Receive diabetes } \\
\text { self-management } \\
\text { booklet }\end{array}$ & $\begin{array}{l}\text { Performance } \\
\text { accomplishment } \\
\text { Verbal persuasion }\end{array}$ & $\begin{array}{l}\text { Chapter } 1 \text { (introduction on what } \\
\text { diabetes is and importance of } \\
\text { managing it) }\end{array}$ & & \\
\hline & $\begin{array}{l}\text { Watch first episode } \\
\text { of movie }\end{array}$ & $\begin{array}{l}\text { Verbal persuasion } \\
\text { Self-evaluation }\end{array}$ & $\begin{array}{l}\text { To understand what diabetes is and } \\
\text { the importance of managing it }\end{array}$ & & \\
\hline Week 2 & $\begin{array}{l}\text { Diabetes self- } \\
\text { management } \\
\text { booklet }\end{array}$ & $\begin{array}{l}\text { Performance } \\
\text { accomplishment } \\
\text { Verbal persuasion }\end{array}$ & $\begin{array}{l}\text { Chapter } 3 \text { (exercise) } \\
\text { Chapter } 4 \text { (foot care) } \\
\text { Chapter } 7 \text { (healthy living with } \\
\text { diabetes) }\end{array}$ & $\begin{array}{l}\text { To be able to identify self- } \\
\text { management problems and } \\
\text { develop strategies to solve } \\
\text { those problems, including } \\
\text { self-selected behavioral goal } \\
\text { setting and action plan } \\
\text { To be able to understand the } \\
\text { importance of exercise } \\
\text { To be able to understand the } \\
\text { importance of foot care } \\
\text { To be able to understand and } \\
\text { manage difficult emotions }\end{array}$ & $\begin{array}{l}\text { Problem solving and } \\
\text { self-directed goal } \\
\text { setting and action } \\
\text { plan } \\
\text { Exercise } \\
\text { Risk reduction } \\
\text { Coping skills }\end{array}$ \\
\hline \multirow{2}{*}{ Week 3} & $\begin{array}{l}\text { Diabetes self- } \\
\text { management } \\
\text { booklet }\end{array}$ & $\begin{array}{l}\text { Performance } \\
\text { accomplishment } \\
\text { Verbal persuasion }\end{array}$ & $\begin{array}{l}\text { Chapter } 2 \text { (healthy eating) } \\
\text { Chapter } 5 \text { (self-monitoring blood } \\
\text { glucose) } \\
\text { Chapter } 7 \text { (healthy living) }\end{array}$ & \multirow{2}{*}{$\begin{array}{l}\text { To be able to identify self- } \\
\text { management problems and } \\
\text { develop strategies to solve } \\
\text { those problems, including } \\
\text { self-selected behavioral goal } \\
\text { setting and action plan } \\
\text { To be able to understand the } \\
\text { importance of healthy eating } \\
\text { To be able to understand the } \\
\text { importance of self-monitoring } \\
\text { blood glucose } \\
\text { To be able to understand the } \\
\text { benefit of regular blood } \\
\text { pressure check-up } \\
\text { To be able to understand and } \\
\text { manage pain and fatigue }\end{array}$} & \multirow{2}{*}{$\begin{array}{l}\text { Coping skills } \\
\text { Risk reduction } \\
\text { Healthy eating } \\
\text { Monitoring } \\
\text { Problem solving and } \\
\text { self-directed goal } \\
\text { setting and action } \\
\text { plan }\end{array}$} \\
\hline & $\begin{array}{l}\text { Watch the third } \\
\text { episode of the } \\
\text { movie }\end{array}$ & $\begin{array}{l}\text { Verbal persuasion } \\
\text { self-evaluation }\end{array}$ & $\begin{array}{l}\text { Introduce the benefits of healthy } \\
\text { eating } \\
\text { Introduce self-monitoring blood } \\
\text { glucose }\end{array}$ & & \\
\hline
\end{tabular}


Table 2 (continued)

\begin{tabular}{|c|c|c|c|c|c|}
\hline Time & Intervention & $\begin{array}{l}\text { Self-efficacy theory } \\
\text { application }\end{array}$ & Content & Objective & $\begin{array}{l}\text { ADA } 7 \text { self-care } \\
\text { behavior application }\end{array}$ \\
\hline \multirow[t]{3}{*}{ Week 4} & $\begin{array}{l}\text { Fourth group } \\
\text { practice session }\end{array}$ & $\begin{array}{l}\text { Performance } \\
\text { accomplishment } \\
\text { Vicarious experience } \\
\text { Verbal persuasion } \\
\text { Self-evaluation }\end{array}$ & $\begin{array}{l}\text { To introduce medications (watch } \\
\text { movie and discussion) } \\
\text { To introduce depression } \\
\text { management (watch movie and } \\
\text { discussion) } \\
\text { To introduce positive thinking } \\
\text { (discussion) } \\
\text { To discuss diabetes and your daily } \\
\text { life (watch movie) }\end{array}$ & \multirow{3}{*}{$\begin{array}{l}\text { To be able to understand the } \\
\text { importance of taking } \\
\text { medications } \\
\text { To be able to understand the } \\
\text { importance of depression } \\
\text { management } \\
\text { To be able to think positively } \\
\text { To be able to understand the } \\
\text { importance of healthy living } \\
\text { with diabetes } \\
\text { To be able to identify self- } \\
\text { management problems and } \\
\text { develop strategies to solve } \\
\text { those problems, including } \\
\text { self-selected behavioral goal } \\
\text { setting and action plan }\end{array}$} & \multirow[t]{3}{*}{$\begin{array}{l}\text { Medication } \\
\text { Coping skills } \\
\text { Risk reduction } \\
\text { Problem solving and } \\
\text { self-directed goal } \\
\text { setting and action } \\
\text { plan }\end{array}$} \\
\hline & $\begin{array}{l}\text { Diabetes self- } \\
\text { management } \\
\text { booklet }\end{array}$ & $\begin{array}{l}\text { Performance } \\
\text { accomplishment } \\
\text { Verbal persuasion }\end{array}$ & $\begin{array}{l}\text { Chapter } 6 \text { (medication taking) } \\
\text { Chapter } 7 \text { (healthy living with } \\
\text { diabetes) }\end{array}$ & & \\
\hline & $\begin{array}{l}\text { Watch the fourth } \\
\text { episode of the } \\
\text { movie }\end{array}$ & $\begin{array}{l}\text { Verbal persuasion } \\
\text { Self-evaluation }\end{array}$ & $\begin{array}{l}\text { To introduce medications } \\
\text { To introduce depression } \\
\text { management }\end{array}$ & & \\
\hline $\begin{array}{l}\text { Weeks } \\
5-12\end{array}$ & $\begin{array}{l}\text { Telephone follow- } \\
\text { up }\end{array}$ & $\begin{array}{l}\text { Performance } \\
\text { accomplishment } \\
\text { Verbal persuasion } \\
\text { Self-evaluation }\end{array}$ & $\begin{array}{l}\text { To build trust and rapport } \\
\text { Agenda setting } \\
\text { Negotiate the agenda } \\
\text { Assess readiness to change and } \\
\text { confidence } \\
\text { Explore ambivalence } \\
\text { Set an action plan }\end{array}$ & $\begin{array}{l}\text { To be able to identify self- } \\
\text { management problems based } \\
\text { on the selected agenda and } \\
\text { develop strategies to solve } \\
\text { those problems, including } \\
\text { self-selected behavioral goal } \\
\text { setting and action plan }\end{array}$ & $\begin{array}{l}\text { Healthy eating } \\
\text { Exercise } \\
\text { Monitoring } \\
\text { Medication } \\
\text { Risk reduction } \\
\text { Coping skills } \\
\text { Problem solving and } \\
\text { self-directed goal } \\
\text { setting and action } \\
\text { plan }\end{array}$ \\
\hline
\end{tabular}

from round two. Finally, in round three, the final version of the intervention was developed. The content of the intervention was assessed on a 5-point Likert scale ranging from 1 (totally disagree) to 5 (totally agree). The assessment form contains three items measuring content/style ( 9 sub-item), layout ( 6 sub-item), and visuals (8 sub-item). Items that received the score below $70 \%$ were subjected to be reviewed and reassessed.

In the first round of the Delphi process, the following topics were discussed: (1) healthy diet, (2) physical activity, (3) medication adherence, (4) monitoring, (5) prevention of short and longterm complication of diabetes, and (6) healthy living with diabetes. Based on the expert recommendations, the first draft of the intervention was generated.

In round two, the responses of the experts on the content of the intervention were analyzed. The following results were obtained: neither agree nor disagree $(n=1)$, agree $(n=5)$, strongly agree $(n=17)$. No disagreement was expressed by any of the experts. Item-by-item review of the instrument revealed that $77.7 \%$ strongly agreed with the content/style, $66.6 \%$ strongly agreed with the layout, and $75 \%$ strongly agreed with the visuals. The experts' ideas, suggestions, and corrections were used to revise the intervention.

In round three, the revised draft of the intervention was circulated to all experts for comments and agreement. The responses of the experts on the revised content of the intervention were analyzed, and the following results were obtained: agree $(n=4)$, strongly agree $(n=19)$. No disagreement was expressed by any of the experts. Item-by-item review of the instrument revealed that
$77.7 \%$ strongly agreed with the content/style, $83.8 \%$ strongly agreed with the layout, and $87.5 \%$ strongly agreed with the visuals. Based on the results of the Delphi techniques, it can be concluded that the face and content validity of the intervention was confirmed.

\section{Organizing the Content}

In accordance with the above findings, the study intervention consisted of: (1) receiving a detailed information booklet, which includes information on performing self-management; (2) viewing four 10-min movie clips; (3) attending four weekly groupbased sessions; and (4) receiving weekly follow-up telephone calls. An overview of our intervention content is presented in Table 2.

\section{Receiving the Booklet}

The booklet consisted of six sections: (1) diet; (2) physical activity; (3) medication; (4) monitoring of blood glucose; (5) foot care; and (6) healthy living with diabetes. The booklet was developed based on the two sources of self-efficacy, that is, verbal persuasion and performance accomplishment. Participants in the intervention group received the booklet at the start of the program. The content of the booklet was used throughout the entire length of the intervention to direct further learning, elaboration, and discussion or to create resources for self-directed learning. The content of the booklet was developed from the publicity available websites of the American Diabetes Association [30] and "learning about diabetes" by Paul Tracy [31]. Permission to reprint and translate the educational materials was obtained from the author. 
Watching Movie Clips

For the first 4 weeks of the intervention, participants were invited to watch four 10-min weekly movie clips. The movie expands on the content of the booklet. The language used in the movies was Persian. Movie clips were designed by the research team to provide coaching and encouragement (verbal persuasion). Based on the educational contents, four movies were produced in different fields of diabetes self-management including general information about T2DM, preventing short- and long-term complications (session 1), physical activity, daily foot care (session 2), healthy eating (session 3), and healthy living with diabetes (session 4). The movie clips are available at: https://www.youtube.com/channel/UC2a6jPMufi06J6Q1RRG6cDg.

\section{Group Discussion Sessions}

Four group discussion sessions were carried out at weekly intervals, but the scheduling was flexible, and the seating was limited to 10 participants for each session. These sessions were carried out weekly during the first 4 weeks of the intervention. Each session lasted for $120 \mathrm{~min}$. The focus of these sessions was on building knowledge, self-efficacy, and skills regarding self-goal setting, action plan, problem-solving, sharing, and peer support. A diabetes specialist nurse with 4 years of clinical experience facilitated the group discussion sessions. All group members were heartened to actively participate in each session. Group members who miss a session received a follow-up from the facilitator before the next session. Standard guidelines were developed for the group discussions and used in all the sessions held. At the last meeting of the group session, all group members received a list of residential phone numbers and were encouraged to ask for help if needed.

Receiving Telephone Follow-Up Calls

Two months after the end of the group discussion sessions, intervention participants received a phone call once per week. Each follow-up call lasted approximately 15-20 min. The purpose of the telephone calls was to foster continued performance accomplishment via positive verbal persuasion. Telephone calls were based on principles of motivational interviewing (MI), that successfully help patients to engage and support them in making better health choices [32]. The first step in MI is to set the agenda for the consultation together with the patients [33]. "Agenda setting" is an issue to keep in the back of the patient's mind from the opening scene of the interview. The basic question was "what are we going to talk about today?" Patients were encouraged to choose one or more key items (agenda settings) as their main area of concern. Then, the researcher assessed the participant's current selfcare behavior and motivation for behavior change by rating and exploring importance and confidence with respect to the chosen key items. Techniques that were applied in the telephone calls to invoke the spirit of MI were asking open-ended questions, affirmations, reflective listening, summarizing during a conversation, expressing empathy, developing discrepancy, rolling with resistance, supporting self-efficacy, and reinforcing positive changetalk and new behavior. It led to an action plan being drawn up to implement strategies to improve the patient's performance [34]. Standard guidelines were developed for telephone follow-up interviews.
Pre-Testing and Revising Draft Materials of the Intervention

The study was conducted in an outpatient clinic of an academic hospital in Ilam, Iran (August 2016). A sample of 14 adults with T2DM from the clinic was recruited as the study sample. Patients were eligible for the study if they: (1) were aged 18 years and above; (2) had been diagnosed with T2DM at least 6 months ago; (4) were able to read and write Persian language; and (5) had no hearing and vision impairment. Recruitment was conducted through advertisements on the notice boards of the clinic. Assistance was also sought from the medical personnel for the recruitment. A research assistant assessed patients who were interested in participation for eligibility using a screening instrument. All eligible participants were contacted by phone to set up an appointment. Those who attended received an explanatory statement detailing the study and were informed that all data would be anonymous and strictly confidential. Those agreeing to take part were asked to review and sign a consent form. The pre-testing of the intervention took 1 month to complete. The pre-testing was conducted in accordance with the study protocol as shown in Table 2 . All participants received the booklet, viewed the movie clips, and were asked to attend four group practice sessions at weekly intervals. Participants had to participate in at least three of the four sessions. At the end of fourth group discussion sessions, all participants were asked to comment on comprehension, attraction, and acceptability of the provided information. They also were asked to fill out a brief, three-page evaluation form and provide input on the booklet, movie (language use, font size, use of pictures, the content of information, and suggestion for improvement in the future), and the group discussion sessions. The evaluation lasted 20-30 min. The comments from 14 eligible subjects resulted in modification and validation of the study intervention. The vast majority of them (87\%) gave positive input on comprehension, attraction and, acceptability of the provided information. They also stated they had no difficulties in understanding the content of intervention (booklet, movies, and four group discussion sessions), and they all expressed willingness to receive follow-up telephone calls. There were only minor suggestions on the colors, the use of graphics, pictures, and adding more examples. The draft materials were revised based on the suggestion obtained.

\section{Evaluation and Protocol Amendment}

Evaluation of the Booklet

The evaluation form for the booklet content consisted of five items (ranging from 1 to 10 points) measuring language use, font size, use of pictures, the content of information, and suggestions for improvement. The rating scale is designed from very difficult to understand (1) to very easy to understand (10). The result of the evaluation of the booklet shows that for the first four questions in the booklet evaluation form (language use, font size, use of pictures, content of information), almost all of the participants rated the diabetes booklet in the range of $7-10$, while only a few (7.1\%) rated it as 6 , and none as $<5$. Therefore, we can conclude that the vast majority of the participants found that diabetes booklets were easy to read, easy to understand, simple, and interesting. General comments and suggestions for improving the diabetes booklet are presented in Table 3 .

Evaluation of the Movie Clips

The evaluation form for the movie clips consisted of five items (ranging from 1 to 10 points) measuring language use, use 
Table 3. General comments and suggestions for improving the content of the intervention

\begin{tabular}{|c|c|}
\hline Intervention content & Participants' comments and suggestions \\
\hline $\begin{array}{l}\text { General comments on } \\
\text { the booklet }\end{array}$ & $\begin{array}{l}\text { "The booklet content addresses program goals/objectives" } \\
\text { "The content of the booklet is easy to read and understand" } \\
\text { "The content is dated and effective" } \\
\text { "The pictures are really good" } \\
\text { "I can easily remember what I have learned due to good logical and definite } \\
\text { sequences among different chapters and lessons" } \\
\text { "The booklet is really perfect" }\end{array}$ \\
\hline $\begin{array}{l}\text { Suggestions for } \\
\text { improvement of the } \\
\text { booklet }\end{array}$ & $\begin{array}{l}\text { "Distribute the booklet to other patients" } \\
\text { "The teaching and learning activities are really satisfying, learning in small groups } \\
\text { and using problem-based process results in the improvement of the satisfaction and } \\
\text { quality of the program. I hope this program can be maintained and continue with } \\
\text { more sessions" } \\
\text { "Add the table of content to the booklet" } \\
\text { "Include fasting and diabetes" } \\
\text { "Include sexual activity and diabetes" } \\
\text { "Include more pictures, it is really interesting" }\end{array}$ \\
\hline $\begin{array}{l}\text { General comments on } \\
\text { the movie clips }\end{array}$ & $\begin{array}{l}\text { "The movies are really perfect, easy to understand and interesting" } \\
\text { "The content of the movie is well designed and arranged" } \\
\text { "The movie is clearly presented and addresses my needs" } \\
\text { "Pictures of the scene from the movie are interesting. Funny and simple!" }\end{array}$ \\
\hline $\begin{array}{l}\text { Suggestions for } \\
\text { improvement of the } \\
\text { movie clips }\end{array}$ & $\begin{array}{l}\text { "Distribute the movie to other patients" } \\
\text { "Add music background to the videos" } \\
\text { "It would be amazing if you provided the movie description" }\end{array}$ \\
\hline $\begin{array}{l}\text { Suggestions for } \\
\text { improvement of the } \\
\text { group discussion } \\
\text { sessions }\end{array}$ & $\begin{array}{l}\text { "Conduct the group discussion for other diabetics in the clinic" } \\
\text { "Regular group discussion should be scheduled with diabetes patients to discuss the } \\
\text { diabetes care problems and difficulties and suggest solutions" }\end{array}$ \\
\hline
\end{tabular}

of pictures, the content of information, and suggestions for improvement. The result of the evaluation of the movie clips shows that for the first three questions in the movie evaluation form (language use, use of pictures, the content of information), almost all of the participants rated the movies in the range of 7-10 and none rated them as $<6$. Therefore, we can conclude that the vast majority of the participants found that the movie clips were easy to understand, simple, and interesting. General comments and suggestions for improving the movie clips are presented in Table 3.

Evaluation of the Group Discussion Sessions

The evaluation form consisted of both open-ended questions (questions 1-4) and 10-point Likert-type questions (questions 5-11).

For the first question (What portions were the most valuable?), participants provided the following answers: "problem-solving skills," "the group discussion makes me feel like I am not the only one who has a problem with lifestyle," "action plans were really great, I like it," "this session provides fresh content to me," "I became more enthusiastic towards my responsibilities to be competent in care."

Developing and Validating the Study Intervention
For the second question (What portions would you give more time to?), the majority of the participants provided the following answers: "action plan," "reflection," "providing a list of solutions for my problem."

For the third question (What portions would you shorten or delete?), the following answers were provided: "I need every detail of the discussion, my answer is none," "I do not want to delete any part, and I love our discussion."

For the fourth question (If you had to change something, what would you change?), the following answer was provided: "doctors at the clinic should provide more education on diabetes," "give more example of problems on living with diabetes and overcoming the problems in more detail."

With regard to questions 5-11, participants were asked to answer "how confident they are in managing their condition in terms of different aspects of diabetes self-management" using a Likert scale response ranging from not confident at all (1) to totally confident (10). Almost all participants rated the level of their confidence in the range of $7-10$, while only $7.1 \%$ of participants rated it as 6 and none as $<5$. Therefore, we can conclude that the vast majority of participants feel confident about managing their diabetes. Suggestions for improvement of the group discussion sessions are presented in Table 3. 


\section{Discussion}

Choosing the materials that are suitable for the research objectives can be challenging. To enhance the patient's self-management of diabetes, there is clearly a need to develop new materials written in Persian in order to provide an update and comprehensive information on T2DM. This study aimed to develop and validate a nurseled DSME suitable and tailored for the Iranian society. Thus, the researchers tried to follow the American diabetes association (ADA) guidelines on developing the intervention.

All rules could not, however, be completely followed, particularly due to the amount of detailed information that was provided to patients based on the research objectives and the use of culturally familiar photo illustrations. Our study intervention contains a lot of information that probably seems overwhelming for the research participants. When developing the research intervention, the westernized graphics and pictures were inevitably used that might be intimidating or distracting. These issues have been a major limitation in an attempt to develop new information materials. In order to overcome these issues, the developed intervention was pre-tested with T2DM patients attending an endocrine clinic in an urban-based teaching hospital. Following pre-testing of the program, minor modifications were made, including correction of spelling errors, changing some photographic illustrations, addition of examples (to give an increased understanding of the intervention), and field monitoring of data collection. Moreover, for continuous improvement, an initial evaluation of the program was conducted. This evaluation is made of 5 items including plain language, font size, picture content and content of the information they received. Participants were also asked to provide comments, ideas, and suggestions to further improve the intervention. Participants in this study were highly satisfied with the intervention. As noted in the evaluation process, participants gave high ratings on all evaluation items. Participants indicated that our developed intervention was easy to interpret and understand, easy to read, comprehensive yet simple and interesting. Presumably, these optimistic results might be due to the following reasons:

1. Diabetic educational programs are rarely offered in public healthcare facilities in Iran.

2. DSME that is consistent with the ADA guidelines is not routinely given in most hospitals.

3. The close involvement of patients and caregiver was encouraging.
4. The group-based discussion was employed to encourage participants to become actively involved in the discussion. This can help patients to share their view and experience on the topics and interact with other members during the discussion. Group-based discussion can help patients develop knowledge and skills specific to collaborative efforts. This can also allow them to receive encouragement and social support in order to achieve the best outcomes. In the subsequent group discussion sessions, the group dynamic and interaction among participants might wake their interest in receiving the intervention.

5. For many participants of this project, it was the first time they had ever conducted research; thus, they were very excited about it.

6. Participants were provided with a comprehensive set of training materials, which they could refer to any time. This has, reportedly, increased their enthusiasm and adherence to the intervention. They even asked to share or discuss the content of intervention materials with their family members, relatives, and those people who have the same condition hoping that others may learn more about the illness. Overall, the study intervention was very well received and appreciated by the respondents. The participants were then invited to comment and give suggestions for improvement and general feedback. The vast majority of the respondents were strongly positive about the intervention; they thought the intervention was useful. They were positive about the program, the number of sessions, and its duration.

\section{Conclusion}

In summary, this paper aims to develop and validate diabetes education material (written in Persian) that is suitable and tailored for use by Iranian patients with T2DM. The main reason for developing new diabetes materials has been the unavailability of suitable materials in Persian. Developing new materials, it turns out, is not easy. Widespread use of ADA guidelines can help to standardize management of diabetes. Based on collective expertise, and the best available evidence, the ADA guideline was used to develop a multicomponent intervention for T2DM self-management. In the evaluation phase, the majority of participants provided very positive feedback with regard to the level of information and education they received, which left them confident and reassured in their own self-management. The quality and consistency of the 
ADA guideline may possibly enhance the effectiveness and feasibility of intervention. Further research is needed to determine the effectiveness of implementing this intervention more broadly in diverse healthcare settings. A quantitative description of the effect of the intervention is presented elsewhere [35].

\section{Acknowledgements}

The authors would like to thank the patients for their participation in this study.

\section{Statement of Ethics}

Ethical approval was obtained from the University Putra Malaysia (UPM) ethics committee for research involving human subjects, Malaysia, as well as the ethics committee of the Ilam University of Medical Sciences, Iran.

\section{Disclosure Statement}

The authors declare that they have no conflicts of interest.

\section{Funding Sources}

This work was supported by Ilam University of Medical Sciences (grant No. 943006/146).

\section{Author Contributions}

G.A. drafted the manuscript, and all authors contributed substantially to its revision.

\section{References}

1 Gadsby R. Epidemiology of diabetes. Adv Drug Deliv Rev. 2002 Nov;54(9):1165-72.

2 Lusignan S, Sismanidis C, Carey IM, DeWilde S, Richards N, Cook DG. Trends in the prevalence and management of diagnosed type 2 diabetes 1994-2001 in England and Wales. BMC Fam Pract. 2005 Mar;6(1):13.

3 Adeghate E, Schattner P, Dunn E. An update on the etiology and epidemiology of diabetes mellitus. Ann N Y Acad Sci. 2006 Nov; 1084(1):1-29.

4 Wild S, Roglic G, Green A, Sicree R, King H. Global prevalence of diabetes: estimates for the year 2000 and projections for 2030. Diabetes Care. 2004 May;27(5):1047-53.

5 International Diabetes Federation. Prevalence of Diabetes. 2015. http://reports.instantatlas.com/report/view/846e76122b5f476fa6 ef09471965aedd/IRN.

6 Esteghamati A, Gouya MM, Abbasi M, Delavari A, Alikhani S, Alaedini F, et al. Prevalence of diabetes and impaired fasting glucose in the adult population of Iran: National Survey of Risk Factors for Non-Communicable Diseases of Iran. Diabetes Care. 2008 Jan;31(1):968.

7 Shaghaghi A, Ahmadi A, Matlabi H. Iranian patients require more pertinent care to prevent type 2 diabetes complications. Adv Prev Med. 2014;2014:409391.

8 Funnell MM, Brown TL, Childs BP, Haas LB, Hosey GM, Jensen B, et al. National standards for diabetes self-management education. Diabetes Care. 2009 Jan;32 Suppl 1:S87-94.

9 Haas L, Maryniuk M, Beck J, Cox CE, Duker $\mathrm{P}$, Edwards L, et al. National standards for diabetes self-management education and sup- port. Diabetes Educ. 2012 Sep-Oct;38(5):61929.

10 Shakibazadeh E, Bartholomew LK, Rashidian A, Larijani B. Persian Diabetes Self-Management Education (PDSME) program: evaluation of effectiveness in Iran. Health Promot Int. 2016 Sep;31(3):623-34.

11 Mohebi S, Azadbakht L, Feizi A, Sharifirad G, Kargar M. Review the key role of self-efficacy in diabetes care. J Educ Health Promot. 2013 Jul;2(1):36.

12 Didarloo AR, Shojaeizadeh D, Gharaaghaji Asl R, Habibzadeh H, Niknami S, Pourali R. Prediction of self-management behavior among Iranian women with type 2 diabetes: application of the theory of reasoned action along with self-efficacy (ETRA). Iran Red Crescent Med J. 2012 Feb;14(2):86-95.

13 Zareban I, Niknami S, Rakhshani F. The Effect of Self Efficacy Education Program on Reducing Blood Sugar Levels in Patients with Type 2 Diabetes (HEHP). Health Educ Health Promot 2013;1(1):67-79.

14 Taba H. Curriculum development: Theory and practice. New York: Harcourt, Brace \& World; 1962.

15 American Association of Diabetes Educators. AADE guidelines for the practice of diabetes self-management education and training. Diabetes Educ. 2009;35(3):85-107.

16 Norris SL, Lau J, Smith SJ, Schmid CH, Engelgau MM. Self-management education for adults with type 2 diabetes: a meta-analysis of the effect on glycemic control. Diabetes Care. 2002 Jul;25(7):1159-71.

17 Ellis SE, Speroff T, Dittus RS, Brown A, Pichert JW, Elasy TA. Diabetes patient educa- tion: a meta-analysis and meta-regression. Patient Educ Couns. 2004 Jan;52(1):97-105.

18 Jarvis J, Skinner TC, Carey ME, Davies MJ. How can structured self-management patient education improve outcomes in people with type 2 diabetes? Diabetes Obes Metab. 2010 Jan;12(1):12-9.

19 Haas L, Maryniuk M, Beck J, Cox CE, Duker P, Edwards L, et al.; 2012 Standards Revision Task Force. National standards for diabetes self-management education and support. Diabetes Care. 2013 Jan;36(1 Suppl 1):S1008.

20 Agema P, Sherifali D. Determining the Impact of an Intervention to Increase ProblemSolving Skills in Diabetes Self-Management: The Diabetes Problem-Solving Passport Pilot Study. Can J Diabetes. 2012;36(4):199-203.

21 Mensing CR, Norris SL. Group education in diabetes: effectiveness and implementation. Diabetes Spectr. 2003;16(2):96-103.

22 Gambling T, Long AF. The realisation of patient-centred care during a 3-year proactive telephone counselling self-care intervention for diabetes. Patient Educ Couns. 2010 Aug; 80(2):219-26.

23 Funnell MM, Brown TL, Childs BP, Haas LB, Hosey GM, Jensen B, et al. National standards for diabetes self-management education. Diabetes Care. 2009 Jan;32(1 Suppl 1):S87-94.

24 Weinstock RS, Brooks G, Palmas W, Morin PC, Teresi JA, Eimicke JP, et al. Lessened decline in physical activity and impairment of older adults with diabetes with telemedicine and pedometer use: results from the IDEATel study. Age Ageing. 2011 Jan;40(1):98105 
25 Trief PM, Teresi JA, Eimicke JP, Shea S, Weinstock RS. Improvement in diabetes selfefficacy and glycaemic control using telemedicine in a sample of older, ethnically diverse individuals who have diabetes: the IDEATel project. Age Ageing. 2009 Mar;38(2):219-25.

26 Trief PM, Teresi JA, Izquierdo R, Morin PC, Goland R, Field L, et al. Psychosocial outcomes of telemedicine case management for elderly patients with diabetes: the randomized IDEATel trial. Diabetes Care. 2007 May; 30(5):1266-8.

27 Franciosi M, Lucisano G, Pellegrini F, Cantarello A, Consoli A, Cucco L, et al.; ROSES Study Group. ROSES: role of self-monitoring of blood glucose and intensive education in patients with Type 2 diabetes not receiving insulin. A pilot randomized clinical trial. Diabet Med. 2011 Jul;28(7):789-96.
28 Fan L, Sidani S. Effectiveness of diabetes selfmanagement education intervention elements: a meta-analysis. Can J Diabetes. 2009; 33(1):18-26.

29 Norris SL, Engelgau MM, Narayan KM. Effectiveness of self-management training in type 2 diabetes: a systematic review of randomized controlled trials. Diabetes Care. 2001 Mar;24(3):561-87.

30 American Diabetes Association. Type 2 Diabetes Basics. 2015 [Accessed April 08 2015]. Available from: http://www.diabetes.org/diabetes-basics/type-2/.

31 Tracy P. Learning about diabetes. 2015 [Accessed 12 June 2015]. Available from: https:// www.learningaboutdiabetes.org/.
32 Bundy C. Changing behaviour: using motivational interviewing techniques. J R Soc Med. 2004;97(44 Suppl 44):43-7.

33 Miller W, Rollnick S. Motivational interviewing: preparing people for change. J Healthc Qual. 2003;25(3):46.

34 Jansink R, Braspenning J, van der Weijden T, Niessen L, Elwyn G, Grol R. Nurse-led motivational interviewing to change the lifestyle of patients with type 2 diabetes (MILD-project): protocol for a cluster, randomized, controlled trial on implementing lifestyle recommendations. BMC Health Serv Res. 2009 Jan;9(1):19.

35 Azami G, Soh KL, Sazlina SG, Salmiah MS Aazami S, Mozafari M, et al. Effect of a NurseLed Diabetes Self-Management Education Program on Glycosylated Hemoglobin among Adults with Type 2 Diabetes. J Diabetes Res. 2018;2018:4930157. 